\title{
Determining the basic composition and total phenolic compounds of Pleurotus sajor-caju cultivated in three different substrates by solid state bioprocess
}

\author{
Marcelo Fossa da Paz ${ }^{1^{*}}$, Carlos Alexandre Breyer ${ }^{2}$, Rafael Fontana Longhi ${ }^{2}$ and Manuel \\ Salvador Vicente Plata Oviedo ${ }^{3}$
}

${ }^{1}$ Faculdade de Ciências Biológicas e Ambientais; Universidade Federal da Grande Dourados; 79825-070; Dourados - MS - Brasil. ${ }^{2}$ Núcleo Biotecnológico; Universidade do Oeste de Santa Catarina; Videira - SC - Brasil. ${ }^{3}$ Universidade Tecnológica Federal do Paraná; Campo Mourão - PR - Brasil.

\begin{abstract}
Oyster mushrooms (Pleurotus sajor-caju) were grown in grape bagasse, apple pomace or bean straw. Samples were taken for each one of the substrates and analyzed for moisture, ash, carbohydrate, crude fat, crude fiber, crude protein content and total phenolic compounds. The substrate affected all the parameter content and mainly the total phenolic compounds. In general, the nutritional aspects of mushrooms produced using grape bagasse tended to be better. Changes in the total phenolic compound content of the fruit could be explained by the biosorption capacity from substrate. It was possible to confirm that composition depends on cultivation substrate.
\end{abstract}

Key-words: $P$. sajor-caju, nutritional composition, oyster mushroom, phenolic compounds, grape bagasse, Apple pomace

\section{INTRODUCTION}

Mushrooms are popular in both the Eastern and Western regions of the world because they are delicious, and their production has increased massively over recent years.

Culturing edible mushrooms on grape bagasse and apple pomace seems especially attractive, since it represents a direct conversion of an agricultural waste into human food.

It is known that mushrooms are nutritious foods. Compared to vegetables, they are high in protein and have a good balance of vitamins and minerals: calcium, phosphorus, iron, magnesium, soluble and insoluble fiber, beta-glucans, chitin, phenolic compounds and ribonuclease (Silva et al., 2002; Ngai and Ng, 2004; Manzi et al., 2004; Mattila et al., 2002). Mushrooms contain few digestible carbohydrates and a low amount of fat (Ramos et al., 2003). These aspects make mushrooms suitable for low-calorie diets. Moreover, mushrooms offer therapeutic benefits due to their antimicrobial, antimitogenic, antiproliferative (Ngai and Ng 2004; Tambekar et al., 2006), antimutagenic (Lakshmi et al., 2004) and antiviral
(Yang et al., 2001) properties. The composition depends on the cultivation substrate and cultivation conditions (Badalyan, 2003).

However, the results of analyses vary widely for all constituents. This variation may be caused by differences in strain, substrate and the developmental stage of the mushroom (Mattila et al., 2002; Tam et al., 1986; Mizuno and Zhuang, 1995). The knowledge of the relationship between the properties of the mushrooms and agricultural waste characteristics can contribute to the improvement of quality of the products (Ragunathan et al, 1996). Apple pomace, a byproduct of the juice processing industry, is a rich source of many nutrients including carbohydrates, minerals and fibers, although there is a low protein, vitamin and mineral content, which contributes to the low nutritional level and consequently low commercial value of the residue (Devrajan et al., 2004; Villas-Bôas et al., 2003). On this note, the protein enrichment of this raw material using miceliation can transform it into a good nutrient source due to fungal nutritional properties. The same is true for grape bagasse.

Author for correspondence: mfpaz9@gmail.com 
In the present study, a strain of Pleurotus sajorcaju was cultured on grape bagasse, apple pomace and bean straw (as the standard). The purpose was to characterize differences in total phenolic composition and proximate composition.

\section{MATERIAL AND METHODS}

Mushroom Cultivation: A commercial strain of Pleurotus sajor-caju was maintained through successive tolling in potato dextrose agar, and was cultivated based on the method used by Paz et al. (2006).

Drying and Harvest: The mushrooms were harvested for three days after pinheads started appearing and dried immediately at $90^{\circ} \mathrm{C}$. They were then crushed, producing mushroom flour.

Proximate Analysis: The proximate compositions of the three mushroom flour treatments, including moisture, ash, carbohydrate, crude fat, crude fiber and crude protein, were determined according to
AOAC methods (1990). The nitrogen factor used for crude protein calculation was 4.38 , based on the method used by Yang et al. (2001) to determine mushroom protein levels.

Total Phenolic Compound Determination: The fungal phenolics were determined using the FolinCicalteal procedure. Gallic acid was used as the phenol standard to represent the relationship between the concentration of phenolics and absorbance, which was read at $765 \mathrm{~nm}$ based on the method used by Asolini et al. (2006).

\section{RESULTS AND DISCUSSION}

All results are summarized in Table 1. Through a comparison of the results, it is possible to confirm that are no significant differences between the three substrates in terms of ash and fats, although fiber presented a higher difference, especially on the apple pomace cultivated mushrooms.

Table 1. Mushroom composition on different substrates: bean straw, apple pomace and grape biogases.

\begin{tabular}{|c|c|c|c|c|c|c|c|}
\hline Substrate & $\begin{array}{l}\text { Crude Fiber } \\
\text { (g/100g dry } \\
\text { weight) }\end{array}$ & $\begin{array}{c}\text { Humidity } \\
(\%)\end{array}$ & $\begin{array}{c}\text { Crude } \\
\text { Protein } \\
\text { (g/100g } \\
\text { dry } \\
\text { weight) }\end{array}$ & $\begin{array}{l}\text { Crude Fat } \\
\text { (g/100g } \\
\text { dry } \\
\text { weight })\end{array}$ & $\begin{array}{c}\text { Ash } \\
\text { (g/100g } \\
\text { dry } \\
\text { weight) }\end{array}$ & $\begin{array}{c}\text { Carbohydrates } \\
\text { (g/100g dry } \\
\text { weight) }\end{array}$ & $\begin{array}{c}\text { TPC } \\
\text { (mg/100 } \\
\text { g dry } \\
\text { weight) }\end{array}$ \\
\hline $\begin{array}{l}\text { Bean } \\
\text { straw }\end{array}$ & 16.55 & 4.01 & 16.30 & 3.26 & 6.26 & 53.62 & 56.26 \\
\hline $\begin{array}{l}\text { Apple } \\
\text { pomace }\end{array}$ & 10.58 & 5.22 & 24.44 & 3.84 & 6.12 & 49.80 & 88.91 \\
\hline $\begin{array}{l}\text { Grape } \\
\text { bagasse }\end{array}$ & 19.60 & 6.81 & 27.83 & 3.12 & 7.05 & 35.59 & 205.23 \\
\hline
\end{tabular}

*Calculated using the NIFEXT difference.

Graphic 1 displays the percentages found for the mushrooms produced on each substrate. Accordingly, the differences in the fruiting body composition might also be a result of the availability and/or ease of nutrient uptake by the mushroom on the different substrates as well as its composition, mainly because this mushroom has a high biosorption capacity.

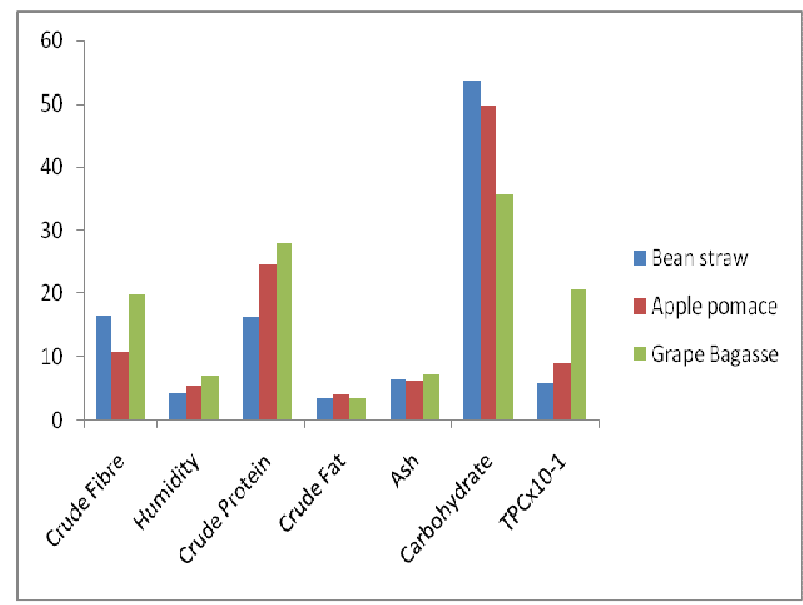

Figure 1 - Comparison of Proximate Analysis for the Mushrooms Produced on each Substrate: Bean straw, apple pomace and grape bagasse. Fiber, Proteins, Lipids, Ashes and Carbohydrates are expressed in 
grams for every $100 \mathrm{~g}$ of mushroom. The humidity (\%) and Total Phenolic Compound are expressed in grams for every $\mathrm{mg} / 100 \mathrm{~g}$ of mushroom.

Nevertheless, the similarity in all composition profiles reported in the literature suggests that all parameter content may be affected quantitatively by the substrate.

Apparently, the results shown that, nutritionally, the mushrooms produced on grape bagasse show the best profile for the analyzed parameters, especially the low quantity of fat and carbohydrates and higher amount of protein and total phenolic composition.

Surprisingly, the crude fiber on mushrooms produced using grape bagasse presented more crude fiber than bean straw, although this consists of pectocelulosic material as opposed to being of a lignocellulosic nature. This is also good in terms of the nutritional aspect, since foods with elevated levels of alimentary fiber, high protein content and low carbohydrates and fat are desirable. The same is true of ashes, which represent the mineral content. However, further studies must be performed before drawing any final conclusions.

\section{CONCLUSIONS}

It was possible to confirm that composition depends on the cultivation substrate, as previously proven by other authors.

Changes in the total phenolic compound content of the fruit can be explained by the biosorption capacity due to substrate or induction factors, and the grape bagasse appears to be the best substrate since it naturally contains more phenolic compounds that may contribute to increasing the phenolic composition of mushroom.

\section{REFERENCES}

AOAC, (1990), Official Methods of Analysis, 14th ed.; Association of Official Analytical Chemists: Washington, DC.

Asolini, F. C.; Tedesco, A. M.; Carpes, S. T.; Ferraz, C.; Alencar, S. M. (2006), Atividade Antioxidante e Antibacteriana dos Compostos Fenólicos dos Extratos de Plantas Usadas como Chás. Brazilian Journal of Food Technology, 9, 209-215.

Badalyan, S. M. (2003), Edible and Medicinal Higher Basidiomycetes Mushrooms as a Source of
Natural Antioxidants. International Journal of Medicinal Mushrooms, 5, 153-163.

Devrajan, A.; Joshil, V. K.; Gupta, K.; Sheikher, C.; Lal, B. B. (2004), Evaluation of Apple Pomace Based Reconstituted Feed in Rats After Solid State Fermentation and Ethanol Recovery. Brazilian Archives of Biology and Technology, 47, 93-106.

Lakshmi, B.; Jose, N.; Ajith, T.; Janardhanan, K. K. (2004), Antimutagenic Activity of Methanolic Extract of Culinary-Medicinal Oyster mushroom, Pleurotus ostreatus (Jacq.:Fr.) Kumm. (strain florida Eger nom. nud.) and Its Protective Effect Against Benzo [a] Pyrene-Induced Hepatic Damages. International Journal of Medicinal Mushrooms, 6, 139-150.

Manzi, P.; Marconi, S.; Guzzi, A.; Pizzoferrato, L. (2004), Commercial mushrooms: nutritional quality and effect of cooking. Food Chemistry, 84, 201-206.

Mattila, P.; Salo-Väänänen, P.; Konko, K.; Aro, H.; Jalava, T. (2002), Basic Composition and Amino Acid Contents of Mushrooms Cultivated in Finland. Journal of Agricultural Food Chemistry, 50, 6419-6422.

Mizuno, T. and Zhuang, C. (1995), Houbitake, Pleurotus sajor-caju: antitumor activity and utilization. Food Review International, 11, 185187.

Ngai, P. H. K. and Ng, T. B. (2004), A ribonuclease with antimicrobial, antimitogenic and antiproliferative activities from the edible mushroom Pleurotus sajor-caju. Peptides, 25, 1117.

Paz, M. F.; Vieira, E.; Breyer, C. A.; Giovanni, R. N.; Bertoldi, F. C. (2006), Cultivo de Pleurotus sajor-caju em bagaço de uva Isabel. Evidência, 6, 187-194.

Ramos, A. C.; Sapata, M. M.; Candeias, M.; Figueiredo, E.; Gomes, M. L. (2003), Cultura de Cogumelos do Gênero Pleurotus. Portugal: INIAP, 605-611.

Silva, S. O.; Costa, S. M. G.; Clemente E. (2002), Chemical composition of Pleurotus pulmonarius (Fr.) Quél., substrates and residue after cultivation. 
Brazilian Archives of Biology and Biotechnology, 45, 531-535.

Tam, S. C.; Yip, K. P.; Fung, K. P.; Chang, S. T. (1986), Hypotensive and renal effects of an extract of the edible mushroom Pleurotus sajor-caju. Life Science, 38, 155-1161.

Tambekar, D. H.; Sonar, T. P.; Khodke, M. V.; Khante, B. S. (2006), The novel antibacterials from two edible mushrooms: Agaricus bisporus and Pleurotus sajor caju. International Journal of Pharmacology, 2, 584-587.

Villas-Bôas, S. G.; Esposito, E.; Mendonça, M. M. (2003), Bioconversion of apple pomace into a nutritionally enriched substrate by Candida utilis and Pleurotus ostreatus. World Journal of Microbiology and Biotechnology, 19, 461-467.
Yang, J. H.; Ching-Lin, H.; Mau, J.-L. (2001), Non-volatile taste components of several commercial mushrooms. Food Chemistry, 72, 465471.

Ragunathan, R.; Gurusamy, R.; Palaniswamy, M.; Swaminathan, K. (1996), Cultivation of Pleurotus spp. on various agro-residues, Food Chemistry, $\mathbf{5 5}, 139-144$. 